\title{
PAIYA LOHUNGO LOPOLI Menemukan Petuah Bijak Agama dan Keagamaan dalam Pantun Khas Gorontalo
}

\author{
Paiya Lohungo Lopoli \\ Discovering Wise Religion Advices in Typical Pantun of Gorontalo
}

Paisal

Balai Litbang Agama Makassar

Jl. AP. Pettarani No. 72 Makassar

Email: umar.faisal@rocketmail.com

Naskah diterima tanggal 25 April 2013. Naskah direvisi tanggal 10 Mei 2013. Naskah disetujui tanggal 20 Mei 2013

\begin{abstract}
Abstrak
Penelitian ini mengkaji unsur-unsur petuah bijak bernilai agama dan keagamaan dalam paiya lohunggo lopoli yang merupakan pantun berbalas yang terdapat di Gorontalo dengan mendeskripsikan unsur ekstrinsik dan intrinsik dalam lirik pantun. Data diperoleh dengan studi pustaka, wawancara dan observasi lapangan. Dapat disimpulkan dalam paiya lohunggo lopoli mengandung nilai-nilai agama dan keagamaan berupa anjuran untuk taat ibadah serta ajaran akhlak/moral, sosial dan bernilai budaya.
\end{abstract}

Kata kunci: nilai agama dan keagamaan, paiya lohungo lopoli, Gorontalo

\begin{abstract}
Abstact
The research discusses the elements of wise advices which have religious values in 'pahiya lohunggo lopoli' which is reciprocated pantun of Gorontalo society by describing intrinsic and extrinsic elements in the pantun lyrics. The data were obtained through literature review, interview and field observation. It can be concluded that 'paiya lohunggo lopoli' comprises religious values such as advice for obeying to perform worship and moral teachings, social and cultural values.
\end{abstract}

Keywords: religious values, paiya lohungu lopoli, Gorontalo

\section{PENDAHULUAN}

$\mathrm{M}$ engamati petuah bijak lokal yang masih hidup dalam masyarakat tidak bisa tidak, harus menyusuri kehidupan sastra secara keseluruhan dan tidak terlepas dari persoalan kesusastraan daerah, khususnya sastra lisan, yang merupakan warisan budaya daerah yang turun temurun dan mempunyai nilai-nilai luhur yang perlu dikembangkan dan dimanfaatkan dalam hubungan dengan usaha menangkal efek negatif globalisasi. Menurut Koentjaraningrat (1987: 85), nilai budaya itu merupakan konsep hidup dalam alam pikiran sebagian besar warga masyarakat mengenai halhal yang harus dianggap bernilai dalam kehidupan. Oleh karena itu, suatu sistem nilai budaya berfungsi sebagai pedoman aturan tertinggi bagi kelakuan manusia, seperti aturan hukum di dalam masyarakat. Nilai budaya itu biasanya mendorong suatu pembangunan spiritual, seperti tahan cobaan, usaha dan kerja keras, toleransi terhadap pendirian atau kepercayaan orang lain, dan gotong royong.

Sastra lisan adalah produk budaya lisan yang diwariskan dari generasi ke generasi melalui mulut, seperti ungkapan tradisional, pertanyaan tradisional, puisi rakyat, cerita rakyat, dan nyanyian rakyat. Usaha menggali nilai keagamaan dalam sastra lisan merupakan penelusuran terhadap unsur kebudayaan daerah yang perlu dikembangkan karena sastra daerah merupakan sumber yang tidak pernah kering bagi kesempurnaan keutuhan budaya nasional bangsa ini. Sastra lisan sebagai produk budaya sarat dengan ajaran moral, bukan hanya berfungsi untuk menghibur, melainkan juga 
mengajar, terutama mengajarkan nilai-nilai yang terkait dengan kualitas manusia dan kemanusiaan.

Di samping itu, terkandung nilai budaya yang sifatnya universal di antaranya nilai keagamaan, nilai kesetiaan, nilai sosial, nilai historis, nilai moral, nilai budaya, nilai etika, dan nilai kepahlawanan. Sastra lisan adalah bagian dari tradisi yang berkembang di tengah rakyat yang menggunakan bahasa sebagai media utama. Sastra lisan ini lebih dulu muncul dan berkembang di masyarakat daripada sastra tulis. Dalam kehidupan sehari-hari, jenis sastra ini biasanya dituturkan oleh seorang ibu kepada anaknya, seorang tukang cerita pada para pendengarnya, guru pada para muridnya, ataupun antar sesama anggota masyarakat. Untuk menjaga kelangsungan sastra lisan ini, warga masyarakat mewariskannya secara turun temurun dari generasi ke generasi.

Provinsi Gorontalo adalah salah satu wilayah otonom dengan penduduk yang terdiri dari tiga sub bahasa yakni Gorontalo, Atinggola dan Suwawa. Seluruh wilayah ini sangat kaya dengan sastra lisan. Sastra lisan di Gorontalo mengandung nilai-nilai budaya dan keagamaan, tumbuh dan berkembang sejalan pertumbuhan dan perkembangan masyarakatnya sehingga memegang peranan penting dalam pembentukan watak sosial masyarakat pendukungnya. Semua wilayah di Gorontalo menjadikan nilai-nilai yang terkandung dalam sastra lisan sebagai pedoman dan prinsip hidup dalam masyarakatnya. Berdasarkan hal tersebut maka penelitian ini berusaha mengungkap petuah bijak yang terdapat dalam masyarakat gorontalo dengan pertanyaan penelitian: Bagaimanakah nilainilai budaya yang terdapat dalam pantun paiya lohungo lopoli di Gorontalo?.

Tujuan penelitian ini untuk menjaga dan melestarikan warisan budaya bangsa dan manfaat penelitian ini adalah terinventarisnya sastra lisan yang terdapat di Gorontalo. Diharapkan dengan tersedianya data dan informasi pemerintah dapat mengambil kebijakan yang tepat dan masyarakat dapat tetap melestarikan salah satu bagian dari kebudayaan tersebut.

Penelitian tentang sastra lisan di Gorontalo telah cukup banyak dilakukan hal ini disebabkan karena banyaknya ragam sastra lisan Gorontalo, salah satunya adalah yang dilakukan oleh Idham dengan judul Pohutu Molalungo (Sinergitas Adat dan Syariat dalam Penyelenggaraan Acara Adat Pemakaman di Pohalaa Gorontalo, Indonesia).
Penelitian ini menitikberatkan perhatiannya pada tradisi lisan yang ada dalam acara pemakaman di Pohalaa Gorontalo, mengupas sinergitas adat dan syariat karena Gorontalo dikenal kental nuansa budaya dan agama dalam setiap ritual kehidupannya (Idham. 2011: 240).

Penelitian tentang kesenian Buruda dilakukan oleh Salmin Djakaria. penelitian tersebut menemukan nilai-nilai yang terkandung dalam bait-bait buruda yakni, nilai religius, moral, sosial dan pendidikan. Sebagai kesenian tradisional buruda bersifat hiburan kepada masyarakat namun didalamnya mengandung fungsi dan makna yang dalam.

Paiya lohungo lopoli merupakan salah satu bentuk kesenian rakyat yang cukup populer di kalangan masyarakat Gorontalo sebagai pendukungnya. Masyarakat pendukungnya menurut Salmin Djakaria (2011: 135), terdiri atas 1) pelaku seni; 2) pencipta seni; 3) penikmat seni; dan 4) pemerintah. Keempat unsur tersebut dipandang sangat berperan dalam pelestarian dan pengembangan kesenian lokal.

Kesenian sebagai budaya dapat dipandang menurut tiga komunitas sosialnya. Para eksekutif dan birokrasi memandang kesenian terutama dalam bingkai warisan yang menjadi identitas bangsa/ daerah. Ilmuan memandang kesenian dalam cakrawala perubahan sosial budaya. Sedangkan praktisi seni/seniman memandang kesenian sebagai agenda daya cipta yang sangat peka terhadap krisis dan kemandekan. Lebih lanjut dijelaskan pada tiga komunitas tersebut, maka praktisi/senimanlah yang memperlakukan seni sebagai pranata sosial tempat berekspresi, berkreasi, melakukan kegiatan produktif (Ignas Kleden dalam Alim S. Niode. 2007: 159).

Adapun pendekatan yang digunakan dalam menganalisa pantun jenis Paiya lo Hunggo Lopoli adalah pendekatan intrinsik dan ekstrinsik. Menurut Nyoman Kutha Ratna (2004: 78-79), bahwa karya sastra dapat dianalisa dengan dua cara. Pertama, menganalisa unsur-unsur yang terkandung dalam karya sastra. Kedua, menganalisa unsur-unsur diluarnya yaitu kebudayaan pada umumnya. Analisa pertama dilakukan melalui pendekatan intrinsik, sedangkan analisa yang kedua dilakukan melalui pendekatan ekstrinsik.

Menurut Suminto Sayuti (1985: 18), puisi memiliki unsur intrinsik yang terbagi atas unsur bentuk dan unsur isi, unsur bentuk adalah bunyi 
(irama dan rima), kata (diksi, suku kata, gaya bahasa) dan tipografi (baris dan bait), unsur isi adalah tema dan pesan. Berdasarkan teori tersebut, penulis membatasi hanya membahas unsur intrinsik bentuk yaitu bunyi (irama dan rima), suku kata, dan tipografi (baris dan bait), serta unsur isi yaitu tema dan pesan.

Selanjutnya mengenai unsur ektrinsik yang membangun menurut Suminto Sayuti (1985: 17), bahwa isi sebuah puisi dibangun oleh unsur ekstrinsik karena unsur ektrinsik adalah isi yang mewarnai karya sastra. Unsur-unsur ekstrinsik yang turut mewarnai karya sastra yaitu, alam, religi, ide, pengalaman, perasaan, dan pandangan lain dari sang pengarang dalam memandang sesuatu di dunia dan kehidupan. Unsur-unsur ekstrinsik itulah yang membuat terciptanya unsur intrinsik isi puisi seperti tema dan pesan.

Unsur ekstrinsik terdiri atas beberapa bagian. Menurut Wellek \& Warren (dalam Artikel online La Muda. 2012), bagian yang termasuk unsur ekstrinsik tersebut adalah sebagai berikut:

1. Keadaan subjektivitas individu pengarang yang memiliki sikap, keyakinan, dan pandangan hidup yang semuanya itu mempengaruhi karya sastra yang dibuatnya.

2. Keadaan psikologis, baik psikologis pengarang, psikologis pembaca, maupun penerapan prinsip psikologis dalam karya.

3. Keadaan lingkungan pengarang, seperti ekonomi ,sosial, dan politik. Pandanganhidupsuatubangsa, berbagai karya seni, agama, dan sebagainya. Malinowski menyebut yang termasuk unsur budaya adalah bahasa, sistem teknologi, sistem mata pencaharian, organisasi sosial, sistem pengetahuan, religi, dan kesenian. Unsur-unsur tersebut menjadi pendukung karya sastra.

Artikel ini merupakan hasil penelitian deskriptif kualitatif dengan sumber informasi dari wawancara dengan pemangku adat Gorontalo, seniman, budayawan dan tokoh masyarakat, dan dilanjutkan dengan observasi dan studi pustaka. Data yang diperoleh dianalisa secara kualitatif.

\section{PEMBAHASAN}

\section{Gorontalo dan Sastra Lisannya}

Menurut sejarah, Jazirah Gorontalo terbentuk kurang lebih 400 tahun lalu dan merupakan salah satu kota tua di Sulawesi selain Kota Makassar, Pare-pare dan Manado. Gorontalo pada saat itu menjadi salah satu pusat penyebaran agama Islam di Indonesia Timur yaitu dari Ternate, Gorontalo dan Bone. Seiring dengan penyebaran agama tersebut Gorontalo menjadi pusat pendidikan dan perdagangan masyarakat di wilayah sekitar seperti Bolaang Mongondow (Sulut), Buol, Toli-Toli, Luwuk Banggai, dan Donggala (Sulteng) bahkan sampai ke Sulawesi Tenggara. Gorontal menjadi pusat pendidikan dan perdagangan karena letaknya yang strategis menghadap Teluk Tomini (bagian selatan) dan Laut Sulawesi (bagian utara).

Sebelum masa penjajahan keadaaan daerah Gorontalo berbentuk kerajaan-kerajaan yang diatur menurut hukum adat ketatanegaraan Gorontalo. Kerajaan-kerajaan itu tergabung dalam satu ikatan kekeluargaan yang disebut "Pohala'a". Daerah Gorontalo terdapat lima Pohala'a yakni Pohala'a Gorontalo, Pohala'a Limboto, Pohala'a Suwawa, Pohala'a Boalemo, Pohala'a Atinggola. Dengan hukum adat itu maka Gorontalo termasuk 19 wilayah adat di Indonesia. Potret sehari-hari masyarakat Gorontalo dikenal sangat kental dengan paduan nuansa adat dan agama di Gorontalo menyatu dengan istilah "Adat bersendikan Syara' dan Syara' bersendikan Kitabullah".

Dalam proses sosialisasi dan komunikasi keseharian masyarakat Gorontalo, selain menggunakan bahasa Indonesia juga menggunakan bahasa daerah, kecuali sebagai salah satu kekayaan budaya, penggunaannya memberi label ciri khas Provinsi Gorontalo. Bahasa dominan dipakai adalah bahasa Gorontalo meskipun masih terdapat tiga bahasa daerah lainnya yakni bahasa Suwawa dan Atinggola, kedua bahasa terakhir hanya dipakai oleh penduduk yang tinggal di kedua kecamatan tersebut dan atau sekitarnya. Hanya saja beberapa tahun belakangan penggunaan bahasa Gorontalo dalam kehidupan sehari-hari telah mulai berkurang. Bahasa yang lebih banyak dipakai adalah Bahasa Indonesia dialek Manado dengan logat Gorontalo. Untuk memasyarakatkan kembali pemakaian bahasa Gorontalo, Pemerintah Kabupaten Gorontalo menghimbau masyarakat untuk selalu menggunakannya dalam berbagai acara misalnya khutbah jumat di masjid-masjid.

Hampir dapat dipastikan penduduk asli Gorontalo seluruhnya memeluk agama Islam (meskipun tentu saja sulit memastikan seberapa jauh kadar keislamannya). Jika tiba-tiba kedapatan ada diantara mereka yang tidak beragama Islam maka hampir dapat dipastikan mereka dari kalangan yang murtad atau keturunannya. Karena 
itu, dulu di Sulawesi Utara dikenal bahwa Gorontalo dari segi agama identik dengan Islam (sedangkan Minahasa identik dengan Kristen). Ketika orang mempertanyakan mengapa demikian? Sebabnya adalah Islam masuk menjadi agama kerajaan di Gorontalo. Lebih lanjut Islam telah menjadi pandangan hidup mendasar yang terpaut (lo tombowata) dengan adat istiadat setempat (Alim S. Niode, 2007: 18). Pandangan hidup tersebut seperti telah diketahui diformulasikan sebagai adat bersendikan syara', syara' bersendikan kitabullah.

Pandangan hidup dan adat istiadat tersebut meyebabkan penduduk asli Gorontalo malu jika disebut bukan Islam (dila tiluna). Bahkan mereka merasa terhina dan tidak jarang menyebabkan pembunuhan. Sedangkan mereka yang murtad sebagian besar harus pindah ke daerah lain. Biasanya mereka tidak lagi menyebut Gorontalo sebagai asalnya.

Gorontalo dikenal memiliki kekayaan dalam tradisi sastra lisan. Menurut Nani Tuloli (2003: 13), varian sastra lisan yang terdapat dalam masyarakat Gorontalo dapat dibedakan berdasarkan ciriciri: mempunyai pilihan kata-kata setiap ragam; memiliki hiasan bunyi awal (anafora) dan akhir (epifora), ulangan konsonan yang sejajar (aliterasi serta ulangan vokal yang sejajar (asonansi); mempunyai nama ragam sendiri yang diketahui oleh masyarakat; mempunyai fungsi praktis sesuai dengan aspek yang terdapat dalam masyarakat; mempunyai tipe pencerita sendiri yang dikukuhkan dengan julukan atau gelar pencerita.

Bertitik tolak dari ciri tersebut Tuloli (2003: 13) membagi jenis sastra lisan : ke dalam tiga ragam yakni:

a. Ragam yang termasuk pada jenis epik dan balada, terdiri dari: tanggomo, merupakan ragam puisi yang berisikan cerita sejarah, kejadian nyata atau yang penting dan menghebohkan. Tanggomo juga bisa berisi mite, legenda, bahkan dongeng, dan fikiran-fikiran yang bersifat filsafat. Tanggomo selalu dilagukan baik dengan menggunakan alat musik maupun tidak. Bungga, yaitu ragam puisi yang bisa digolongkan dalam balada. Isinya adalah cerita yang pendek dan penyajiannya dibawakan dengan irama oleh tukang cerita. Cerita itu biasanya pujaan terhadap seseorang atau keluarga.

b. Lirik, ragam ini menurut Tuloli (2003: 14) sangat banyak macamnya. Dilihat dari fungsinya ragam ini dapat dimasukkan pada puisi adat, filsafat, kata-kata arif, pepatah dan teka-teki. Klasifikasi ragam tersebut adalah tujaqi, yaitu puisi adat yang diucapkan untuk mengiringi upacara peradatan seperti perkawinan, penobatan pejabat, penjemputan dan lain-lain. Tokoh penceritanya adalah baate dan wuqu (gelar pemangku adat dan wakilnya).

1) Palebohu semacam puisi yang berisi pidato, nasihat. Biasanya diucapkan setelah selesai upacara adat. Penceritanya biasanya terdiri dari tokoh adat dan mantan pejabat. Kalau diucapkan oleh tokoh adat (baate dan wuqu) ragam ini diberi nama tahuda, sebaliknya kalau diucapkan oleh mantan pejabat (walikota dan bupati) maka ragam ini dinamakan tahuli.

2) Mala-mala, ragam puisi yang diucapkan sebagai pembuka setiap upacara peradatan. Fungsinya hanya mengingatkan kepada para tamu bahwa upacara adat akan dimulai. Dalam upacara keagamaan, seperti Hari Raya Idul Fitri dan Idul Adha, ragam ini diberi nama khusus yaitu monggumo. Orang yang menyampaikan ragam ini adalah tokoh adat.

3) Taleningo, sejenis puisi filsafat. Isinya mengandung ajaran-ajaran agama Islam atau renungan tokoh atau leluhur. Pada prinsipnya ragam ini berisi peringatan agar manusia berbuat baik di dunia yang kelak akan menentukan corak hidup atau balasan diakhirat. Ragam taleningo, bisa menyangkut kehidupan sebelum lahir, sesudah lahir, dan sesudah mati.

4) Leningo, berisi pikiran dan pendapat para tokoh masyarakat sebagai nasihat untuk memperbaiki tingkah laku. Ragam ini bisa dimasukkan pada puisi pepatah, peribahasa atau kiasan. Kesannya sangat mendalam karena diungkapkan dengan memakai simbol-simbol sebagai pengungkap makna.

5) Lumadu, sejenis teka-teki baik bersifat permainan biasa ataupun ungkapan yang serius. Lumadu juga bisa berbentuk suatu perumpamaan yang isinya menyinggung atau memperluas dan mempertinggi kesan makna yang menjadi sasaran.

6) Bunito, sejenis mantra yang diucapkan oleh pawang-pawang yang disebut wombua. Wombua seringkali berfungsi ganda sebagai pemimpin upacara mantra (menanam dan 
mengetam padi, pergi ke medan perang, naik rumah baru, memakai alat baru) juga sebagai dukun tradisional.

7) Lohidu, ragam ini banyak diciptakan oleh kalangan muda mudi. Lohidu dapat disamakan dengan pantun yang dipakai dalam pergaulan. Ragam ini kalau diungkapkan oleh dua orang (pemuda dan pemudi) dan saling berbalasan diberi nama pahia lohungo lopoli. Sering lohidu diungkapkan dalam dua bahasa, bahasa : dan bahasa Melayu.

\section{c. Ode}

Ragam ini kurang ditemukan lagi dalam masyarakat Gorontalo. Ada satu ragam yang hampir sama dengan bahasan ode, yaitu ragam tinilo. Ragam ini berbentuk syair, yang mengandung sanjungan bagi seseorang. Pada umumnya tinilo dipergunakan pada saat mengantar mayat ke kuburan (Idham: 2011).

Selanjutnya Tuloli (2003: 9) mengungkap dalam menentukan jenis atau ragam dalam sastra lisan dalam masyarakat tidak dapat disamakan. Lebih lanjut dikatakan bahwa peragaman sastra lisan ada umumnya dapat dilihat dari segi (1) bentuk dan isinya, (2) fungsi praktis dalam masyarakat dan budaya, (3) sistem penampilan atau penceritaannya.

\section{Pahiya Lohungo Lopoli dan Nilainya}

Salah satu bentuk kesenian yang sering dipentaskan di Gorontalo adalah pantungi, disebut pantungi ketika seniman penyanyinya tunggal baik hanya seorang laki-laki atau perempuan. Jenis pantun berbalas yang dibawakan dengan berduet antara laki-laki dan perempuan dinamakan paiya lohungo lopoli. Istilah ini berasal dari bahasa Gorontalo (Darwis Abuna. 2008: 1), terdiri dari kata "paiya" berarti melempar, "lo" merupakan kata sambung, "poli" sejenis buah pohon yang ringan. Paiya lohungo lopoli artinya saling melempar katakata yang ringan, dan dapat pula dikatakan saling melempar pantun yang ringan.

Meskipun ringan namun kenyataannya dari pengamatan penulis pada beberapa bait pantun khas Gorontalo ini mengandung makna dan pesan yang sangat dalam. Setiap bait mengandung petuahpetuah yang bisa dijadikan pelajaran, sejalan dengan kebiasaan masyarakat Gorontalo yang pandai merangkai kata dalam menyampaikan nasehat, pendapat dan kritikan dengan tetap menjunjung tinggi sopan santun.

Paiya lohungo lopoli seringkali dilaksanakan ketika ada kegiatan pernikahan, syukuran, keagamaan, pesta panen raya, serta pentas kesenian di kampus-kampus maupun sekolah. Pesertanya berasal dari kalangan muda-mudi Gorontalo yang secara bergantian saling berbalas pantun. Diiringi petikan gambus (ada pula yang menggunakan gitar) dan tepukan marwas. Berikut adalah salah satu syair Paiya lohungo lopoli (Darwis Abuna, 2008: 6-8);

\section{Putra}

Bisimillah pomulai

Bisimillah polumulo

Dulolo po ambu mayi

Pantungi mulaiyalo

Putri

Palemu tumu-tumulo

Uwanggu mali ngokoli

Bisimillah polumulo

Paiya hungo lo poli

Putra

Poo piyohe hu hutu

Huhutumu ode tamu

Tabiya utowakutu

Parenda lo isilamu

Putri

Paotuluhe li hapusa

Amongiyo peya-peya

Motabiya mopuasa

Parenda liyo lo eya

Putra

Holontalo waw limutu

Bo tuwawa lo warisi

Quruani dutu-dutu

Pangei mao lo hadisi

Putri

Alimu dila obutu

Polihuwau suhuru

Quruani dutu-dutu

Uwito lali ukuru

Putra

Awasi mali pu lolo

Mongodulaa kawasa

Suhur ma bongulolo

Sarati liyo lo puasa

Putri

Longola lali odiya

Longola bo odelami

Mopuasa motabiya

Hilawo sana-sanangi
Putra :

Bismillah memulai Bismillah mengawali Mari berkumpullah Pantun segera dimulai

Putri :

Padimu sudah tumbuh

Sepertinya bisa jadi sekoli

Bismillah mengawali

Pantun berbalasan

Putra :

Perbaikilah tingkah laku Tingkah lakumu kepada tamu

Solatlah pada waktunya Perintah agama Islam

Putri :

Tempat tidurnya Hafsa Alasnya tempat solat Solat dan berpuasalah Itu perintah Tuhan

Putra :

dan Limboto

Adalah satu warisan

Al quran telah tersedia

Pasangannya adalah Hadits

Putri :

Sumurmu tidak bermata air Untuk mandi aku saat sahur Al quran telah tersedia Itu yang menjadi ukuran

Putra :

Hati-hati menjadi dosa Orang tua yang berhak Sahur akan dibangunkan Sebagai syaratnya puasa

Putri :

Mengapa jadi begini Mengapa hanya kepada kami Berpuasa dan solatlah

Hati menjadi senang 
Putra

Pomondo mayi hutiya

Mapohutuu balati

Mamolihara tabiya

Parenda lo sareati

Putri

Sambe damango hulu'u

Untungi ma ngobalati

Tabuyamu mauhusuu

Mootapu barakti

\section{Putra}

Pohama mayi taniya

Poluwangau tamate

Harata bo to dunia

Amali delola mate

Putri

Moti huloo to bangga

Hemogalipo kuyini

Harata ma bangga-

bangga

Bagiya de misikini

Putra

Malo sambe lo olohu

Monao umulo-mulo

Hale ma sambe piyohu

Modali tumu-tumu lo

Putri

Dilaboti poorsas

Mali tuwanga lolati

Eyando tama kawasa

To dunia akherati

Putra

Polipu pomayi kando

Tubuwa wolo kamate

Isilamu agamando

Delola sambe u mate

Putri

Pohama mayi popati

Mapomatiu oliyo

Mopuasa mo zakati

Uwoto parenda liyo

Putra

Dipayi mayi labiya

Pohutuwo yilabulo

Mopuasa motabiya

Modali tumu-tumulo

\section{Putri}

Pantungi mayilapato

Diyambagalo oato

Maafu tangoa-ami

Pohalinga de olami
Putra :

Ambillah rotan

Akan kujadikan keranjang

Menjaga solat

Sebagai perintah syareat

Putri :

Sungguh besar hulu'u (jenis

ikan yang hidup di danau)

Untungnya sudah

sekeranjang

Solatmu sudah khusyu'

Akan mendapatkan berkat

Putra:

Ambilkan tempat

Untuk kuisikan tomat

Harta hanya di dunia

Amal dibawah mati

Putri :

Sedang duduk di kursi

Sedang mengupas kuyini

Harta sudah bertumpuk

Bagikan kepada orang

miskin

Putra :

Sungguh orang yang rajin

Berjalan yang dimulakan

Hati yang sungguh baik

Modal untuk hidup

Putri :

Jangan terlalu merasa

Akan dirasuki setan

Tuhan kitalah yang berkuasa

Di dunia dan akhirat

Putra :

Petiklah kangkung

Masaklah dengan tomat

Islam agama kita

Dibawa sampai mati

Putri :

Ambilkan cangkul

Untuk mencangkulnya

Berpuasa dan berzakat

Itu adalah perintah-Nya

Putra :

Ambilkan sagu

Akan dibuatkan yilabulo

(makanan khas)

Berpuasa dan solatlah

Modal untuk hidup

Putri :

Pantun telah selesai

Langkahkan kaki

Mohon maaf kepada

semuanya

Kembalikanlah kepada kami
Setelah membaca pantun di atas, dapat kita temukan unsur instrinsik dan ekstrinsik pantun. Unsur instrinsik pantun ditentukan dengan menemukan hakikat pantun yakni bertema sosial religius. Pesan yang disampaikan dalam pantun di atas sangat beragam berisi pesan moral keagamaan dan kemanusiaan. Nadanya menghimbau atau menyindir orang-orang yang melanggar larangan agama dan akibat-akibat yang akan diperolehnya kemudian hari. Sedangkan unsur ekstrinsik pantun tersebut adalah religiusitas.

Bentuk pantun khas Gorontalo tersebut selalu mengikuti kaidah yang terdiri dari empat larik dan pantun di atas tersusun sebanyak 18 bait. Terjadi pertautan antara setiap larik yang pertama dengan yang ketiga dan larik kedua dengan larik keempat yang saling berhubungan. bunyi akhir larik pertama sama dengan larik ketiga, Bunyi akhir larik kedua sama dengan larik keempat.

Setiap larik dalam Paiya lohungo lopoli mempunyai bunyi akhir yang sama. Bunyi akhir larik pertama sama dengan bunyi akhir larik ketiga. Bunyi akhir larik kedua sama dengan bunyi akhir larik keempat. Larik pertama dan ketiga mempunyai bunyi akhir yang sama yaitu $i$ dari kata pomulai dan mayi. Larik kedua dan keempat mempunyai bunyi akhir lo dari kata polumulo dan mulaiyalo. Dengan demikian, pantun di depan mempunyai rima a b a b, demikian pula dalam bait berikutnya sampai akhir. Unsur ekstrinsik pantun tadi tampak dalam isi pantun yang mengajak pembaca untuk tidak melupakan hubungan kepada Tuhan dan juga hubungan kepada sesama manusia. Jadi unsur ekstrinsik pantun yang tampak adalah religiusitas dan sosial.

Tema pantun yang ditemukan dalam isi. Tema pantun di atas adalah agama dan keagamaan. Tema ketuhanan digambarkan hampir dalam setiap larik diawali dengan kata bismillah sebagai ajakan untuk selalu menyandarkan diri pada Tuhan dalam setiap mengawali sesuatu pekerjaan. Dilanjutkan dengan pesan sosial memperbaiki tingkah laku utamanya kepada tamu. Gorontalo sejak dulu terkenal sebagai tempat yang ramah bagi pendatang, pada masa pemerintahan Sultan Eyato (Raja Eyato memerintah tahun 1673 s/d 1679 disebut sebagai raja terbesar dalam sejarah Gorontalo, pada masa pemerintahannyalah Kerajaan Gorontalo mencapai masa keemasannya. Dikenal sebagai diplomat ulung, berhasil mendamaikan perang saudara dengan Limboto yang telah berlangsung kurang 
lebih 187 tahun (Tahun 1485 - 1672). Peninggalan terbesar lainnya yang masih bertahan sampai saat ini adalah konsep prinsip dasar/falsafah "adati hulohuloqa tosaraqa, saraqa hulo-huloqa to kuruqani". (Adat bersendi syara', syara' bersendikan kitabullah) pendatang dan penduduk asli di Gorontalo disebutkan mempunyai kedudukan yang sejajar. Hal ini terekam dalam salah satu sajak Raja Eyato (DK. Usman. Wawancara. 2012) pada tahun 1672 ketika menerima tamu yang bukan suku Gorontalo.

$\begin{array}{ll}\begin{array}{ll}\text { Tobutu to payango } \\ \text { Hulawa mo eyango } \\ \text { To pateda to etango }\end{array} & \begin{array}{l}\text { Orang asli orang asing } \\ \text { Pada gelang pada ikat } \\ \text { pinggang }\end{array} \\ \begin{array}{l}\text { To patali to milango } \\ \text { To duhe deu tongango }\end{array} & \text { Di dada maup pelabuhan dimulut } \\ \text { To payango to bulu } & \text { Orang asing orang asli } \\ \text { Hutawa otutu } & \text { Emas murni } \\ \text { Tilulube pilu-pilutu } & \text { Dibakar dipotong-potong } \\ \text { To latahu molutu } & \text { Kuning asli } \\ \text { To tapalu to bututu } & \text { Dikotak dipundi-pundi } \\ \text { Wange lo ilomala } & \text { Pasangan hasil karya } \\ \text { Tonulahu to pohutu } & \text { Hiasan pada upacara }\end{array}$

Sajak ini menurut DK Usman (wawancara: 2012) bermakna:

1. Orang asli dan orang asing datang ke : tidak dibedakan lagi, sama-sama mempunyai hak hidup;

2. Semua mempunyai kehormatan yang sama, dimanapun mereka berada;

3. Tetapi hanya hati yang tahu, sedang mulut harus dikekang/dijaga;

4. Orang asli memang berhak dihormati, karena kemurniannya. Tetapi biasanya tindakannya sendiri yang membuatnya tidak bernilai;

5. Kehormatan hanya diperoleh oleh mereka yang berkarya untuk masyarakat.

Pada dasarnya, kemampuan dasar sosial adalah segala bentuk watak yang dapat menjadi modal (potensi) bagi berlanjutnya interaksi antar sesama warga dari suatu komunitas atau antar warga dari satu kelompok sosial lainnya. Salah satu kemampuan sosial itu adalah kepercayaan. Modal kepercayaan dalam kaitannya dengan interaksi antar sesama sehingga mampu menjaga nilai-nilai kerukunan. Masyarakat Gorontalo, umumnya memiliki sifat seperti itu, karena dibentuk oleh tradisi dan kesopanan kulturalnya. Watak masyarakat Gorontaloseperti itu merupakan modal dasar dan sangat potensial dalam menumbuhkembangkan semangat persaudaraan.

Dilihat dari segi adat masyarakat Gorontalo, adat memiliki makna dan persepsi tersendiri. Adat dipandang sebagai suatu kehormatan (adab), norma, bahkan pedoman dalam pelaksanaan pemerintahan. Hal ini merupakan pengejawantahan dari falsafah "Adat Bersendi Syara," "Syara' Bersendi Kitabullah".

Selanjutnya kandungan pantun adalah mengajak bersembahyang, sembahyang kunci dari segala sesuatu. Dengan demikian, larik keempat pantun mengandung tema dan amanat pantun. Nampaknya saat menulis pantun, penyair merasa prihatin melihat banyak orang yang melupakan hubungan dengan Tuhan. Bait ke empat pantun tersebut tetap berisi pesan sholat dan puasa yang merupakan perintah agama.

Dalam bait kelima pantun tersebut menunjukkan adanya pertautan yang erat antara Gorontalo dan Limboto (Gorontalo dan Limboto seringkali disandingkan sebagai dua kerajaan kembar. Awalnya kerajaan tersebut saling bermusuhan dan terlibat dalam perseteruan yang berujung pada peperangan yang tidak pernah selesai namun sejak lahirnya perjanjian perdamaian antar kedua kerajaan. Tanggal ditandatanganinya naskah perjanjian persaudaraan tersebut pada 12 Sya'ban 1084 Hijriyah, atau sekitar November 1973 Masehi (Farha Daulima, 2006: 13). Jalinan persaudaraan tersebut harus dijaga sebagaimana menjaga warisan, tergambar juga bahwa $\mathrm{Al}$ quran dan hadits senantiasa menjadi rujukan di kedua pohala'a tersebut. Pesan sholat dan puasa ini berlanjut sampai bait-bait selanjutnya. Dikatakan bahwa dengan melaksanakan perintah Allah dalam $\mathrm{Al}$ quran hati akan menjadi senang (baca: tenteram, sebagaimana dalam Al a'raf (13):28, dengan sholat artinya mengingat Allah sehingga jiwa menjadi tenteram). Menjaga sholat yang khusyuk sebagai salah satu syariat Islam akan beroleh keuntungan yang berlipat dan berkah. Sholat khusyuk adalah sholat yang berkualitas yang akan memberikan pengaruh yang kuat dalam mencegah seseorang terhadap perbuatan yang keji dan mungkar. Satusatunya formulasi untuk menghindari perbuatan keji dan mungkar yang dimurkai dan akan diberikan balasan berupa azab neraka oleh Allah bagi orang yang melakukannya adalah sholat. Sholat memiliki efek dan kekuatan untuk mencegah perbuatan keji dan mungkar. Sholat yang bukan sembarang sholat tapi sholat yang memiliki mutu dan kualitas tinggi 
yang dalam bahasa $\mathrm{Al}$ quran disebut dengan istilah sholat khusyuk.

Manusia adalah makhluk yang mudah stress atau panik dan gelisah dalam menjalani setiap episode kehidupan, ketika ditimpa oleh kesusahan karena kesempitan ekonomu atau cobaan yang tiada henti yang datang menyapa diri maka ia akan resah dan gelisah. Ketika diberi kemudahan dan kelapangan rezeki ia akan diselimuti oleh rasa ketakutan dan kecemasan kehilangan apa yang telah dia dapat karena sifat keserakahan telah menggerogotinya. Semua penderitan kehidupan seperti ini tidak akan dialami oleh orang-orang yang mencapai kesempurnaan sholat. Penulis syair pantungi ini rupanya sangat memahami bahwa dengan media sholat bisa memperoleh keuntungan yang paripurna. Menariknya bait ke-10 ini juga menjadi pengantar ke bait selanjutnya.

Bait sebelas pesan yang disampaikan sangat terasa pentingnya bekerja dan beramal, dikatakan harta hanya berguna ketika masih hidup sedangkan amal menjadi bekal setelah mati. Berikut di bait 12 dan 13 kata kerja yang digunakan dirangkai menjadi kalimat himbauan untuk bekerja sehingga bisa beroleh harta dan dengan harta ini jangan lupa terdapat bagian yang harus diberikan kepada kaum miskin. Sholat tentu harus dibarengi dengan rajin bekerja diiringi dengan keikhlasan sehingga menjadi modal untuk menjalani kehidupan yang baik.

Terkadang ritual shalat dianggap hanya bersifat vertikal, antara manusia dengan Allah SWT (Hamblumminallah). Padahal dalam sebuah ayatnya, Allah SWT berfiman: "Dan dirikanlah shalat, tunaikanlah zakat dan rukulah beserta orangorang yang ruku" Al quran surah Al Baqarah (1): 43. Ayat itu menyiratkan bahwa shalat dan ibadah sosial (diantaranya dengan zakat) merupakan 'satu paket' ibadah yang harus dilakukan secara bersamaan. Karena shalat merupakan wakil dari jalur hubungan dengan Allah, sedangkan zakat adalah wakil dari jalan hubungan dengan sesama manusia. Allah swt berfirman, "Tahukah kamu (orang) yang mendustakan agama? Itulah orang yang menghardik anak yatim, dan tidak menganjurkan memberi makan orang miskin. Maka kecelakaanlah bagi orang-orang yang shalat, (yaitu) orang-orang yang lalai dari shalatnya, orang-orang yang berbuat ria, dan enggan (menolong dengan) barang berguna." (Al-Ma'uun (107), 1-7). Dari sini bisa dipahami bahwa orang yang shalat itu dapat dimasukkan ke dalam neraka bilamana shalat mereka tidak membuatnya menjadi pembela kepada fakir miskin dan anak yatim.

Sebagian ulama besar berpendapat, jika shalat adalah tiang agama, maka ibadah sosial (zakat) merupakan mercusuar agama. Atau dengan kata lain shalat merupakan ibadah jasmaniah yang paling mulia. Sedangkan ibadah sosial dipandang sebagai ibadah hubungan kemasyarakatan yang paling mulia. Dengan demikian, shalat dapat dipahami sebagai sarana melatih diri untuk menjaga hak-hak sosial. Menjaga hak-hak orang lain adalah diantara bukti nyata keadilan. Untuk menjaga hak-hak orang lain. Shalat yang juga merupakan ibadah terbaik, mempunyai peran luar biasa dalam mengokohkan kekuatan pengontrol pada diri manusia. Untuk itu, shalat sangat berpengaruh pada perluasan keadilan individu dan sosial. Dengan demikian, shalat pada dasarnya mengajarkan kepada kita untuk terus meningkatkan keimanan secara sosial.

Dalam tradisi masyarakat Gorontalo untuk menumbuhkan semangat dan memeriahkan bulan suci Ramadhan, utamanya pada hari-hari terakhir ketika tiba saatnya menunaikan zakat fitrah dikenal tradisi Tumbilotohe (Menurut DK. Usman. Wawancara: 2012), Tumbilotohe dalam bahasa : terdiri dua suku kata, yaitu tumbilo berarti pasang, dan tohe berarti lampu. Jadi, Tumbilotohe berarti acara pasang lampu. Menurutnya, Tumbilotohe merupakan tradisi masyarakat Gorontalo masa lampau yang sudah berlangsung sejak abad ke-15 M. Tradisi ini dilaksanakan pada 3 malam terakhir menjelang hari Raya Idul Fitri, yaitu pada tanggal 27 hingga 30 Ramadhan, mulai magrib hingga pagi hari).

Tradisi ini menurut Nani Tuloli (wawancara. 2012) adalah salah satu bentuk kebudayaan yang dimunculkan ketika Islam mulai dianut di : . Di masa lampau, pelaksanaan Tumbilotohe dimaksudkan untuk memudahkan umat Islam dalam memberikan zakat fitrah pada malam hari. Pada masa itu, lampu penerangan masih terbuat dari damar dan getah pohon yang mampu menyala dalam waktu lama. Oleh karena semakin berkurangnya damar, maka bahan lampu penerangan diganti dengan minyak kelapa (padalama) dan kemudian diganti dengan minyak tanah. Seiring dengan perkembangan zaman, banyak warga Gorontalo mengganti lampu penerangannya dengan lampu kelap-kelip dalam berbagai warna, meski sebagian warga masih tetap menggunakan lampu minyak 
tanah sebagai penerangan. Lampu-lampu minyak tersebut digantung pada sebuah kerangka kayu yang dihiasi dengan janur kuning. Lebih lanjut menurut Nani Tuloli (Wawancara. 2012) Di atas kerangka itu juga digantung buah pisang sebagai lambang kesejahteraan, dan tebu sebagai lambang kemanisan, keramahan, kemurahan hati, serta kemuliaan menyambut hari raya Idul Fitri.

Pantun menggunakan kata-kata denotasi. Kata-kata denotasi tersebut dirangkaikan dengan baik, sehingga membentuk sebuah kalimat yang mempunyai arti kias. Kalimat tersebut digunakan untuk menyampaikan maksud tertentu. Dalam interaksi penulis dengan Risno Ahaya (Wawancara: 2012) yang merupakan seorang seniman pantun yang selama ini aktif mementaskan pantungi dan pahiya lohungo lopoli. Pegambus yang tunanetra ini telah melestarikan seni bertutur itu lewat lebih dari 200 lagu karya ciptaannya. Pantun yang didendangkan dalam bahasa lokal itu amat akrab dengan kehidupan masyarakat Gorontalo.

Petikan alat musik gambus dan lantunan vokal berisi syair tentang kejadian dalam kehidupan sehari-hari. Mulai dari cinta, lelucon, kritik sosial, hingga dendang religius. Di mata warga Gorntalo, suara dan reputasi lelaki yang tunanetra sejak usia dua tahun ini tak dapat disangkal. Kebolehan seniman alam berusia 38 tahun itu kerap mengisi berbagai acara resmi di tanah kelahirannya. Pemusik gambus yang otodidak ini cukup konsisten dengan budaya leluhur (hal ini kami dengar dari sopir yang mengantar kami ke rumah Risno). Ironisnya, kehidupan pelestari budaya gambus Gorontalo itu sungguh memprihatinkan. Bahkan untuk menghidupi anak istrinya, Risno masih harus mengamen dari pasar ke pasar.

Ketika penulis berkunjung kerumahnya di Kabupaten Gorontalo, Risno Ahaya baru saja tampil dalam pementasan paiya lohungo lopoli dalam sebuah acara dikampus UNG. Meski begitu Risno Ahaya masih "menyuguhkan" pantungi dengan iringan gambusnya, bait demi bait mengalir dengan lancar dan syairnya disesuaikan dengan kedatangan kami dari Makassar, dalam perbincangan kami, Risno Ahaya mengungkapkan seringkali menyelingi dengan kritik-kritik sosial dalam penampilannya, dia menuturkan seringkali dalam menciptakan bait pantun apa yang terlintas dalam fikiran itulah yang diucapkan meski tetap mengikuti kaidah pantun itu sendiri. Pantun yang didendangkannya kebanyakan memuat nasehat dan kritikan bersifat sosial juga bernilai keagamaan. Sayangnya saat ini sangat minim yang mampu mendendangkan pantun jenis ini, Risno Ahaya sendiri mengaku tidak mengajarkan namun hal ini tergantung pada bakat dan minat masyarakat hingga dikuatirkan suatu saat nanti pantun khas Gorontalo tersebut hilang ditelan zaman.

\section{PENUTUP}

Nilai agama dan keagamaan yang terdapat dalam pantun Gorontalo diatas terdiri atas empat nilai yaitu nilai relegius, nilai moral, nilai sosial, dan nilai budaya. Nilai-nilai tersebut tersirat dalam isi Pahiya lohunggo lopoli yang merujuk pada perbaikan moral remaja pada zaman sekarang ini. Nilai religius terungkap yaitu pesan kepada manusia agar selalu ingat kepada Allah. Nilai moral yang terungkap di dalamnya yaitu nasehat bagi semua kalangan baik anak-anak, remaja dan dewasa agar selalu berbuat baik, yang kaya tidak melupakan kewajibannya membantu orang miskin. Nilai sosial yang terungkap yaitu mengenai keadaan sosial dalam masyarakat, bagaimana membangun kerukunan dan menjaga interaksi antar sesama baik pendatang maupun penduduk asli. Nilai budaya yang terungkap yaitu mengenai tradisi-tradisi yang harus dijaga.

\section{UCAPAN TERIMA KASIH}

Ucapan terimakasih penulis sampaikan kepada Kepala Balai Litbang Agama Makassar, semua rekan peneliti, staf serta litkayasa tanpa terkecuali. Spesial buat rekan Husnul Fahimah Ilyas yang bersamasama penulis dalam penelitian di Gorontalo serta atas berbagai masukannya terkait penelitian dan kesempurnaan tulisan ini, juga kepada informan lapangan Prof. Nani Tuloli, ibu Elyana G. Hinta, DK Usman (Baate lo Hulondalo) dan Risno Ahaya (terus berkarya $k a$ '...!). Terima kasih tak terhingga juga disampaikan kepada Dewan Redaksi Jurnal Alqalam yang mengakomodir tulisan ini dalam terbitannya.

\section{DAFTAR PUSTAKA}

Abuna, Darwis. 2008. Paiya Lohungo Lopoli. Gorontalo: Penerbit FSB Universitas Negeri Gorontalo.

Daulima, Farha. 2006. Gorontalo-Limboto dalam Naskah Perjanjian. Limboto: FSP LSM Mbu’i Bungale. 
Djakaria, Salmin. 2011. Buruda; Kesenian Rakyat Gorontalo (Suatu Kajian Awal). Dalam Jurnal Esagenang vol. 9 No. 17 Februari 2011. Balai Pelestarian Sejarah dan Nilai budaya Manado.

Idham. 2011. "Pohutu Molalungo; Sinergitas Adat dan Syariat dalam Penyelenggaraan Upacara Adat pemakaman di Pohala'a Gorontalo". Jurnal Al-Qalam. Balai Litbang Agama Makassar. 2011.

Koentjaraningrat, 1987. Kebudayaan, Mentalitas dan Pembangunan. Jakarta: Penerbit PT Gramedia.
La. Muda. "Kajian Prosa Fiksi”. 2012.

Niode, Alim S. 2007. Gorontalo; Perubahan Nilainilai budaya dan Pranata Sosial. Jakarta: PT Pustaka Indonesia Press (PIP)

Ratna, Nyoman Kutha. 2004. Teori metode dan Teknik Penelitian Sastra. Yogyakarta: Pustaka Pelajar.

Sayuti, Suminto A. 1985. Puisi dan Pengajarannya: Sebuah Pengantar. Semarang: Penerbit IKIP Semarang Press.

Tuloli, Nani. 2003. Puisi Lisan Gorontalo. Jakarta: Pusat Bahasa. 